\title{
THE DICHOTOMY OF INFORMATION TECHNOLOGIES IN PROFESSIONAL TRAINING OF FUTURE IT SPECIALISTS: THE SUBJECT AND THE MEANS OF INSTRUCTION
}

\author{
Oleksandr Malykhin \\ Institute of Pedagogy of the \\ National Academy of Educational Sciences of Ukraine, Ukraine \\ Nataliia Aristova \\ Institute of Pedagogy of the \\ National Academy of Educational Sciences of Ukraine, Ukraine \\ Vasyl Kovalchuk \\ Oleksandr Dovzhenko Hlukhiv National Pedagogical University, Ukraine \\ Roman Popov \\ The Cabinet of Ministers of Ukraine, Ukraine \\ Taras Yarmolchuk \\ Institute of Pedagogy of the \\ National Academy of Educational Sciences of Ukraine, Ukraine
}

\begin{abstract}
The study shows some preferences in the choice of training and learning strategies in university educational process aimed at forming future IT-specialists' digital competence as the main indicator of their professionalism in IT-sphere considering information technologies as being the subject and the means of instruction. The use of information technologies results in rethinking of existing approaches to organizing the educational process of higher school especially when it comes to training future IT-specialists. Information technologies integrated into all spheres of human activities and widely applied to support different industries in commercial, private and public sectors cause ever-growing demand for highly-qualified ITspecialists. In the study the authors consider the range of learning strategies used in the educational process for boosting effectiveness of IT-specialists' digital competence formation as the main indicator of their professionalism in IT-sphere. The study was carried out among 164 future IT-specialists at three higher education institutions in Ukraine from February to May 2019. The researchers found out that all the respondents used contemporary information technologies for learning IT-disciplines, namely, all the students (100.00\%) use contemporary information technologies in their formal learning, 68.80\% - in their non-formal learning, $18.30 \%$ - in a wide range of educational activities that could be regarded as informal learning and only $13.20 \%$ - combining informal and non-formal learning. The obtained data were analyzed qualitatively and quantitatively. As the core result of conducted research the
\end{abstract}


Malykhin et al., 2020. The Dichotomy of Information Technologies in Professional Training of Future it Specialists: the Subject and the Means of Instruction

component matrix of learning strategies was developed showing their hierarchy depending on three factors chosen i.e. traditional, self-directed and collaborative learning.

Keywords: component matrix, digital competence, higher education institutions, information technologies, IT-specialists, learning strategies.

\section{Introduction}

The fast progress of the process of digitization of different fields of human society has radically changed our way of life, the way we work and interact, communicate and collaborate, learn and generate new knowledge. Nowadays, the organization of any activity depends on the use of information technologies, since they are being actively integrated into society and business (Malykhin, 2010; Malykhin, 2016; Vuorikari, Punie, Carretero Gomez, \& Van den Brande, 2016). Information systems are to function properly, to be absolutely safe, to be updated and changed according to some certain professional spheres. IT-specialists have to be highly qualified in order to be able to assist any other specialists in finding the right solutions of the problems connected with the use of information technologies.

The necessity to deepen the contents of professionally-oriented disciplines in the educational process of higher education institutions can be explained by ever-rising needs for improving the quality of future IT-specialists training. The development of students' knowledge, skills and aptitudes requires the corresponding improvement of digital competence of university academic staff and their abilities to use innovative teaching methods (Carretero, Vuorikari, \& Punie, 2017). On the one hand, university teachers who are digitally competent have all the knowledge, skills and aptitudes "to understand how digital technologies can support communication, creativity and innovation, and be aware of their opportunities, limitations, effects and risks" (European Commission, 2018, p. 4). On the other hand, they are ready and able to teach future ITspecialists "to use digital technologies to support their active citizenship and social inclusion, collaboration with others, and creativity towards personal, social or commercial goals" (European Commission, 2018, p. 4). Thus, the new visions of application of information technologies in the educational process with the further perspectives of their use in professional activity and personal life by future IT-specialists prove the topicality and relevance of the study under investigation. The core theoretical underpinnings for conducting the research could be the idea expressed by the team of researchers to consider information technologies in professional training of future IT-specialists as the subject and the means of instruction or, in other words, dichotomically. 


\section{Purpose and Tasks of Research}

The main aim of the paper is to define core preferences in the choice of training and learning strategies in university educational process aimed at forming future IT-specialists' digital competence as the main indicator of their professionalism in IT-sphere considering information technologies as being the subject and the means of instruction. tasks:

The achievement of the principle aim implies completing of the following

1) to select the proper diagnostic methodology and instruments for conducting research;

2) to define core preferences in the choice of training and learning strategies aimed at creating their component matrix considering information technologies dichotomically as being the subject and the means of instruction;

3) to measure future IT specialists' digital competence as the main indicator of their professionalism in IT-sphere.

\section{Research Methodology}

General Characteristics of Research

The research was conducted for one semester (from February to May, academic year 2018/2019. The research took place at Classical Private University (Zaporizhia, Ukraine), National University of Life and Environmental Sciences of Ukraine (Kyiv, Ukraine) and Interregional Academy of Personnel Management (Kyiv, Ukraine).

Research Sample

The research sample consisted of 164 students earning BA in Computer Engineering and Information Technologies at three higher education institutions. The second, third and fourth year students were randomly selected as the research sample. The distribution of respondents is given in Table 1.

Table 1 Distribution of respondents $(N)$

\begin{tabular}{|l|c|c|}
\hline \multicolumn{1}{|c|}{ Higher Education Institution } & $\begin{array}{c}\text { Number } \\
(\mathbf{N})\end{array}$ & $\begin{array}{c}\text { Percentage } \\
\text { (\%) }\end{array}$ \\
\hline Classical Private University & 47 & 28.66 \\
\hline $\begin{array}{l}\text { National University of Life and Environmental Sciences of } \\
\text { Ukraine }\end{array}$ & 63 & 38.41 \\
\hline Interregional Academy of Personnel Management & 54 & 32.93 \\
\hline
\end{tabular}

Source: own study

$N=164$ 
Malykhin et al., 2020. The Dichotomy of Information Technologies in Professional Training of Future it Specialists: the Subject and the Means of Instruction

The distribution of respondents is illustrated in Figure 1.

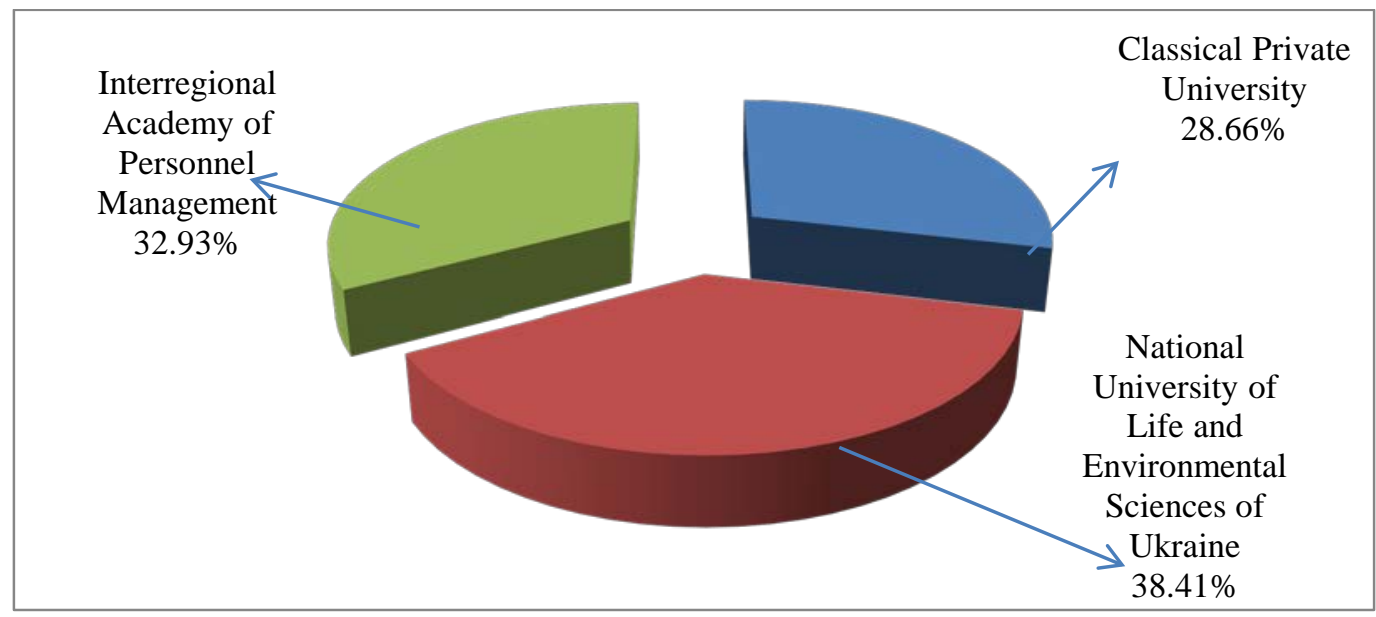

Figure 1 Distribution of respondents

Research instrument

For collecting information the team of researchers created an online questionnaire using Google Forms. The online questionnaire included 30 questions concerning the experience and frequency of information technologies usage in the educational process, types of instruction, forms of organizing instruction, preferences in the choice of teaching and learning strategies etc.

Prior to conducting the online questionnaire, the consent from all respondents was obtained. After conducting the online questionnaire all the obtained findings were evaluated and analyzed using Microsoft Office 2016.

\section{Results and Discussion}

It is found out that all the respondents use contemporary information technologies for learning IT-disciplines (and it is an absolutely obvious result). What is more interesting is the fact that although all the students use contemporary information technologies in their formal learning, 68.80\% - in their non-formal learning, $18.30 \%$ - in a wide range of educational activities that could be regarded as informal learning and only $13.20 \%$ - combining informal and non-formal learning (Fig. 2). 


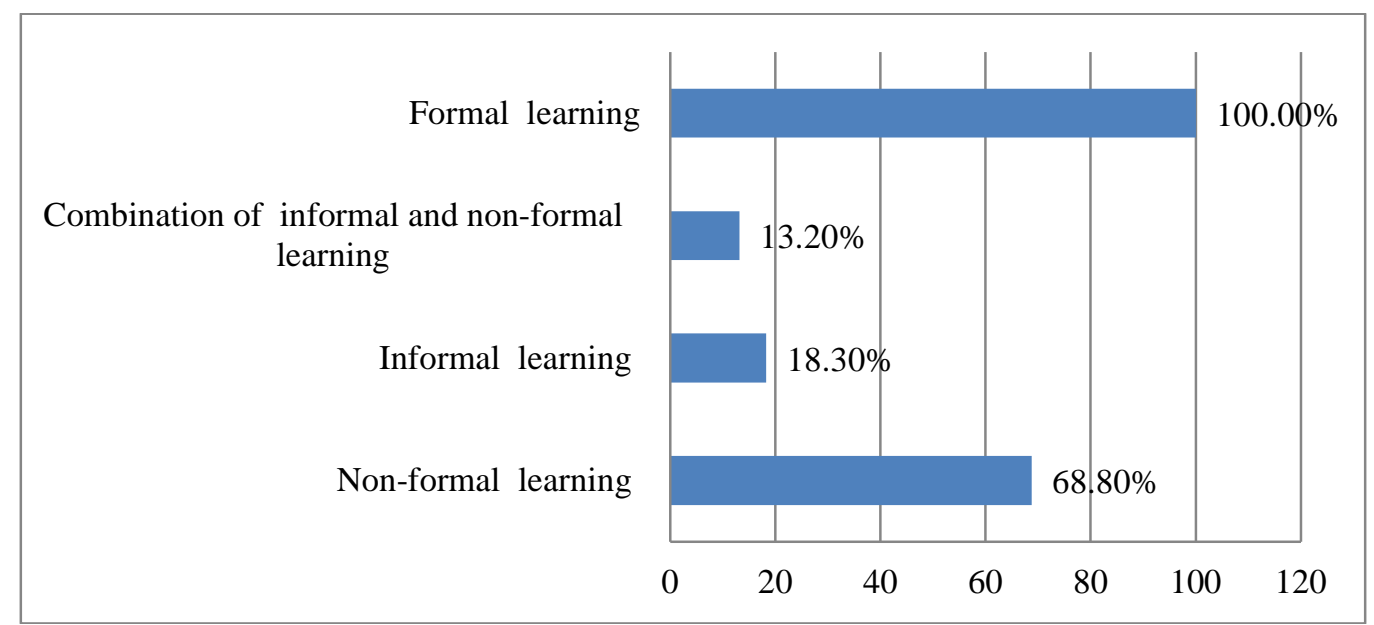

Figure 2 Participation of future IT-specialists in formal, non-formal and informal learning using information technologies

It is axiomatically known that in any higher educational establishment there are different levels at which self-efficacy operates as an important contributor to academic development of both students and teachers. As we mention in one of our previous works (Malykhin \& Aristova, 2018) and sharing the idea by Cherry (Cherry, 2019), teachers (accordingly, teaching staff at university) whose efficacy level is very high are able to motivate and inspire their students, they are also ready to reach the highest level of fulfillment in their workplace aimed at the improvement of future specialists' professionalism in general and future ITspecialists' professionalism from the point of view of the research conducted. So, we may come to a conclusion that one of the actual tasks for teaching staff involved in professional training of future IT-specialists is to continue constantly their non-formal and informal learning as the means of their professional development and to emphasize the importance of their students' being actively engaged in non-formal and informal learning which could be successfully realized under conditions of intensive use of contemporary information technologies (Malykhin, Kovalchuk, Aristova, Popov, \& Hrytsenko, 2017). Such a combination i.e. the combination of formal, non-formal and informal learning based on the use of innovative information technologies is one of the most perspective ways of improving future IT-specialists' professionalism whose core indicator is their digital competence (Malykhin \& Aristova, 2019).

In order to find out the types of learning strategies used by future ITspecialists the factor analysis has been conducted identifying three factors that explain the overall variance (factor $1-61.10 \%$; factor $2-22.58 \%$; factor $3-$ $16.32 \%$. The reliability of the obtained results has been verified by Chronbach' Alfa (An Index of Reliability) that is 0.908 for factor 1 (Traditional learning), 0.754 for factor 2 (Self-directed learning) and 0.672 for factor 3 (Collaborative learning). Table 2 and Table 3 demonstrate that factor values of all components 
Malykhin et al., 2020. The Dichotomy of Information Technologies in Professional Training of Future it Specialists: the Subject and the Means of Instruction

of the research are higher than 0.5. The component matrix of learning strategies is given in Table 2 .

Table 2 Component Matrix of Learning Strategies

\begin{tabular}{|l|c|c|c|}
\hline \multicolumn{1}{|c|}{ Components } & Factor 1 & Factor 2 & Factor 3 \\
\hline Doing definite courses on information technologies & 0.903 & 0.079 & 0.170 \\
\hline $\begin{array}{l}\text { Doing virtual courses that make it possible to apply knowledge } \\
\text { obtained during classes }\end{array}$ & 0.853 & 0.189 & 0.176 \\
\hline $\begin{array}{l}\text { Doing special courses aimed at getting basic knowledge and then } \\
\text { continuing getting knowledge independently }\end{array}$ & 0.812 & 0.030 & 0.361 \\
\hline $\begin{array}{l}\text { Participation in educational events organized by various IT- } \\
\text { associations and specialized groups }\end{array}$ & 0.766 & 0.088 & 0.399 \\
\hline Participation in discussion forums and online social networking & 0.173 & 0.154 & 0.779 \\
\hline Participation in joint projects & 0.254 & 0.135 & 0.689 \\
\hline $\begin{array}{l}\text { Creation of online groups or network communities that support } \\
\text { and motivate to learn IT-disciplines and to use information } \\
\text { technologies }\end{array}$ & 0.576 & 0.079 & 0.654 \\
\hline Consulting an expert on information technologies being studied & 0.460 & 0.271 & 0.513 \\
\hline Using information technologies intuitively and experimentally & 0.149 & 0.902 & 0.043 \\
\hline Preferences of using definite information technologies & 0.053 & 0.799 & 0.302 \\
\hline
\end{tabular}

Source: own study

$N=164$

Table 3 demonstrates the results of the cluster analysis.

Table 3 Cluster Analysis Results

\begin{tabular}{|c|c|c|c|c|c|c|c|c|c|c|}
\hline \multirow{3}{*}{$\begin{array}{l}\text { Learning Strategies } \\
\text { Factors }\end{array}$} & \multicolumn{4}{|c|}{ Cluster Groups } & \multicolumn{6}{|c|}{ Variance Analysis (ANOVA) } \\
\hline & \multirow[b]{2}{*}{1} & \multirow[b]{2}{*}{2} & \multirow[b]{2}{*}{3} & \multirow[b]{2}{*}{4} & \multicolumn{2}{|c|}{ Cluster } & \multicolumn{2}{|l|}{ Error } & \multirow[b]{2}{*}{$\mathrm{F}$} & \multirow[b]{2}{*}{ ISig. } \\
\hline & & & & & $\begin{array}{l}\text { Quadratic } \\
\text { mean }\end{array}$ & Gl & $\begin{array}{l}\text { Quadratic } \\
\text { mean }\end{array}$ & Gl & & \\
\hline Traditional Learning & 9 & 3 & 8 & 3 & 876.659 & 3 & 2.335 & 209 & 353.678 & 0.000 \\
\hline Self-directed Learning & 6 & 3 & 3 & 3 & 19.301 & 3 & 1.888 & 209 & 9.166 & 0.000 \\
\hline Collaborative Learning & 8 & 3 & 5 & 5 & 475.243 & 3 & 2.541 & 209 & 189.644 & 0.000 \\
\hline
\end{tabular}

Source: own study

$N=164$ 
Next step of our research was to find out respondents' level of digital competence in the process of studying professionally-oriented IT-disciplines through using information technologies. The level of future IT-specialists' digital competence was measured by means of 3-point scale (basic level, average level and high level). For showing future IT-specialists' learning strategies as the function of factors depicted on the scale of learning strategies in the process of doing professionally-oriented IT-disciplines, the cluster analysis was carried out and Kolmogorov-Smirnov test was used. The variance analysis (ANOVA) was also used to find out if there were considerable differences in the levels of future IT-specialists' digital competence. Cross-comparison tables to forms of learning in IT-sphere and the level of future IT-specialists' digital competence were applied.

The majority of future IT-specialists preferred self-directed learning and intuitive and experimental learning. It means that they liked to experiment with different information technologies. The learning strategy that future IT-specialists liked the most was to use only those tasks that were of particular interest to them $(\mathrm{M}=3.31 ; \mathrm{SD}=0.873)$. Group-work was the least popular learning strategy used by future IT-specialists $(\mathrm{M}=1.53$; $\mathrm{SD}=1.114)$. And that is an obvious fact as group-work is not typical for IT-specialists at their workplace. The performance of their professional activity does not usually include everyday face-to-face interaction with colleagues and clients. In most cases they work alone with a computer and even if they need anyone's help they get it using a computer and the Internet.

The analysis of obtained results concerning self-directed learning showed that $78.30 \%$ of future IT-specialists used the strategy of using only those information technologies they liked rather than those that were offered by university teachers. It should be noted that $69.70 \%$ of future IT-specialists used the learning strategy of intuitive and experimental learning (Fig. 3).

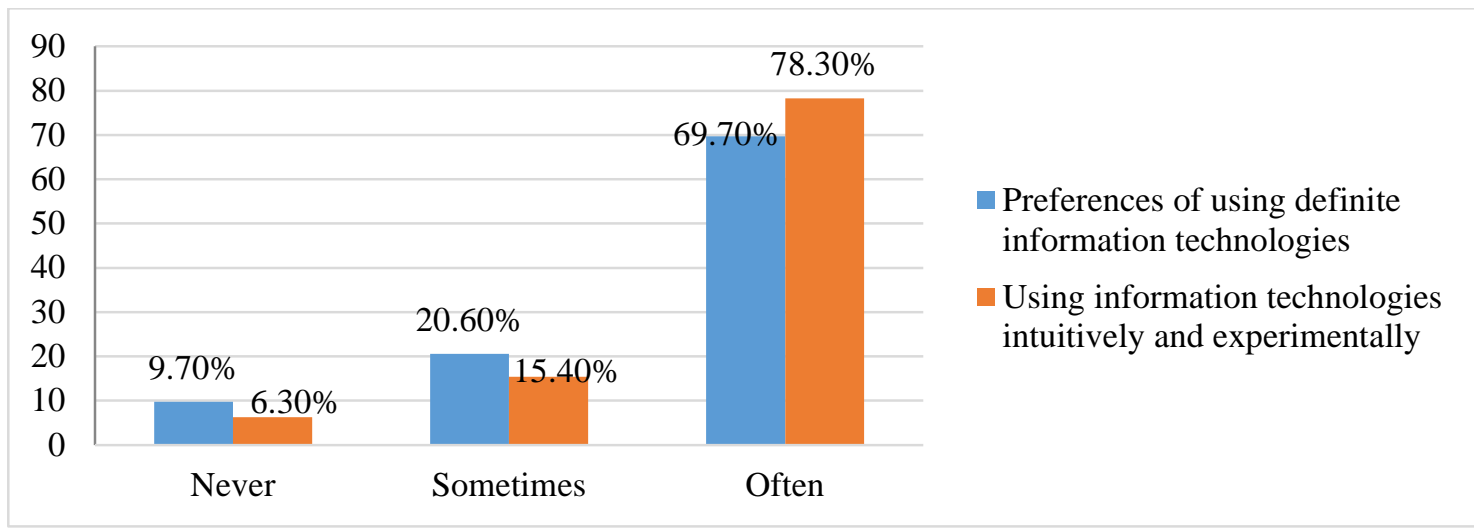

Figure 3 Frequency of using strategies of self-directed learning by future IT-specialists 
Malykhin et al., 2020. The Dichotomy of Information Technologies in Professional Training of Future it Specialists: the Subject and the Means of Instruction

With regard to strategies of collaborative learning, $67.30 \%$ of future ITspecialists thought it would be better to consult an expert and they often used this strategy. $35.30 \%$ of future IT-specialists did not display a desire to become a part of a group or a network for exploring information technologies, while $46.40 \%$ of future IT-specialists used the learning strategy of participating in joint projects (Fig. 4).

Participation in discussion forums and online social networking

Creation of online groups or network communities that support and motivate to learn

IT-disciplines and to use information technologies

Consulting an expert on information technologies being studied

Participation in joint projects

Often

- Sometimes

- Never

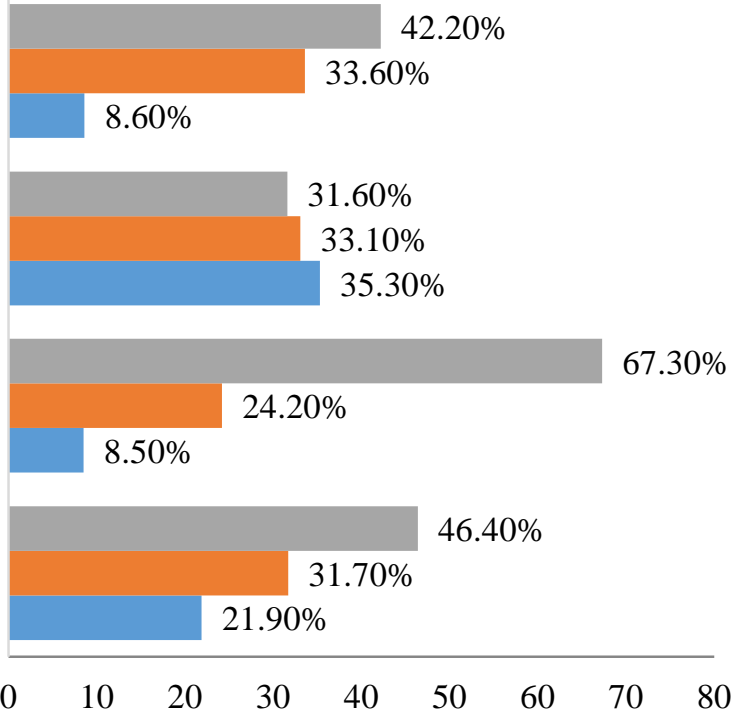

$42.20 \%$

$8.60 \%$

$31.60 \%$

$33.10 \%$

$35.30 \%$

$.30 \%$

80

Figure 4 Frequency of using strategies of collaborative learning by future IT-specialists

Participation in educational events organized by various IT-associations and specialized groups

Doing special courses aimed at getting basic knowledge and then continuing getting knowledge independently

Doing virtual courses that make it possible to apply knowledge obtained during classes

Doing definite courses on information technologies
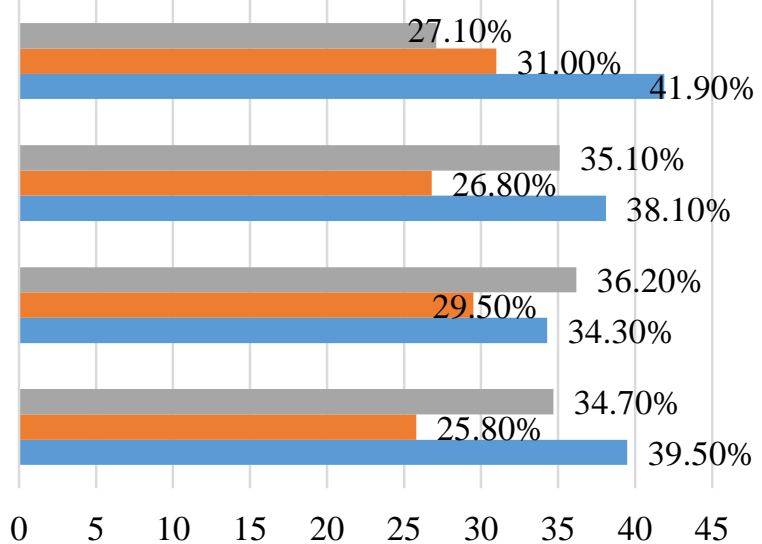

- Often $\quad$ Sometimes $\quad$ Never

Figure 5 Frequency of using strategies of traditional learning by future IT-specialists 
As to traditional learning strategy, $34.70 \%$ of future IT-specialists were interested in doing the courses on working with special applications and digital instruments, whereas $25.80 \%$ of future IT-specialists used this strategy quite seldom. 36.20\% of future IT-specialists preferred doing the virtual courses (Fig. 5).

On the question of the level of future IT-specialists' digital competence, it became clear that $63.60 \%$ of the respondents had an average level of digital competence, $28.30 \%$ showed a high level of digital competence and only $8.10 \%$ demonstrated a basic level of digital competence. The data collection on the question of the future IT-specialists' digital competence level concerned such knowledge and skills as: "Technological knowledge and skills; skills to know what opportunities are provided by different information technologies in the context of IT-specialists' professional activity”; “Knowledge and experience of using technologies for creating digital content; knowledge what technology is the most suitable and effective for a definite type of activity", "Technological knowledge; knowledge on information technologies and their development", "Knowledge on information culture, literacy and safety in information systems".

The obtained results demonstrated the significant differences regarding future IT-specialists' digital competence level depending on their preferences in using learning strategies. Future IT-specialists who often used different information technologies while learning had a higher level of digital competence $(\mathrm{M}=37.5 ; \mathrm{SD}=9.57)$, than future IT-specialists who used more traditional learning strategies $(\mathrm{M}=31.4 ; \mathrm{SD}=9.73)$.

Based on the obtained results four groups of future IT-specialists were identified. Thus, the first group (18.20\%) contained students who studied intensively and expansively and used a wide range of learning strategies (traditional learning, self-directed learning and collaborative learning). 34.30\% of future IT-specialists who preferred self-directed learning, used various information technologies intuitively and experimented with them were a part of the second group. The third group included $27.50 \%$ of future IT-specialists who did not show much enthusiasm and used different information technologies less intensively than the members of the first group. $20.00 \%$ of future IT-specialists who represented the fourth group preferred collaborative learning and developed their digital competence independently using mainly a combination of learning strategies.

Those, who studied intensively and expansively, used various information technologies and all the types of learning strategies, achieved a high level of digital competence $(M=44.256$; $S D=9.073)$. Future IT-specialists who studied less intensively and used only definite information technologies achieved an average level of digital competence $(M=37.153, S D=9.247)$ and the future IT- 
Malykhin et al., 2020. The Dichotomy of Information Technologies in Professional Training of Future it Specialists: the Subject and the Means of Instruction

specialist who preferred self-directed learning $(\mathrm{M}=30.752, \mathrm{SD}=8.601)$ achieved a basic level of digital competence (Fig. 6).

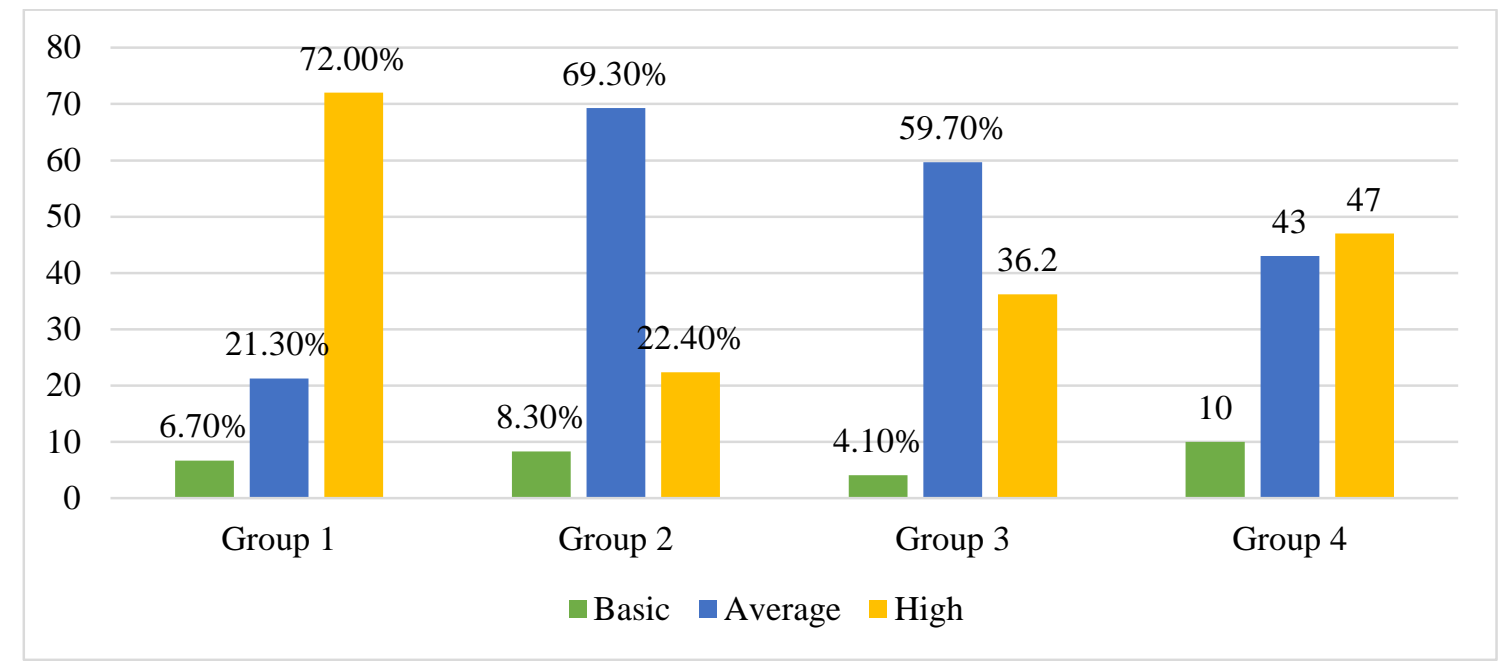

Figure 6 Comparison of digital competence level among the representatives of selected groups

As we can see, the formation of future IT-specialists' digital competence and its level depends greatly on learning strategy chosen and the frequency of using contemporary information technologies for learning IT-disciplines.

\section{Conclusion}

The main aim of our research was to define core preferences in the choice of training and learning strategies in university educational process aimed at forming future IT-specialists' digital competence as the main indicator of their professionalism in IT-sphere considering information technologies as being the subject and the means of instruction. In order to achieve the main aim the team of researchers selected the proper diagnostic methodology and instruments for conducting research, defined core preferences in the choice of training and learning strategies aimed at creating their component matrix considering information technologies dichotomically as being the subject and the means of instruction and measured future IT-specialists' digital competence as the main indicator of their professionalism in IT-sphere. The researchers found out that all the respondents used contemporary information technologies for learning ITdisciplines, namely, all the students $(100.00 \%)$ use contemporary information technologies in their formal learning, $68.80 \%$ - in their non-formal learning, $18.30 \%$ - in a wide range of educational activities that could be regarded as 
informal learning and only $13.20 \%$ - combining informal and non-formal learning.

In the research the authors also considered the range of learning strategies used in the educational process for boosting effectiveness of IT-specialists' digital competence formation as the main indicator of their professionalism in IT-sphere. The conducted analysis became the basis for developing the component matrix of learning strategies showing their hierarchy depending on three factors chosen i.e. traditional, self-directed and collaborative learning. The research proved the idea that the use of information technologies resulted in rethinking of existing approaches to organizing the educational process at higher education institutions especially while training future IT-specialists. Thus, we strongly recommend taking into consideration the data represented in learning strategies component matrix based on three-factor analysis in the process of forming future ITspecialists' digital competence. And the most possible frequency of using contemporary information technologies for learning IT-disciplines is to be guaranteed.

Further research should be aimed at finding out the ways of enhancing the effectiveness of information technologies usage in teaching professionallyoriented disciplines on the basis of implementing adaptive and self-directed learning while training future IT-specialists.

\section{References}

Carretero, S., Vuorikari, R., \& Punie, Y. (2017). DigComp 2.1: The Digital Competence Framework for Citizens with eight proficiency levels and examples of use. [Data file]. Retrieved from https://publications.jrc.ec.europa.eu/repository/bitstream/JRC106281/ web-digcomp2.1pdf_(online).pdf

Cherry, K. (2019). Self Efficacy and Why Believing in Yourself Matters. Retrieved from https://www.verywellmind.com/what-is-self-efficacy-2795954

European Commission. (2018). Annex to the proposal for a council recommendation on key competences for lifelong learning. [Data file]. Retrieved from https://ec.europa.eu/ transparency/regdoc/rep/1/2018/EN/COM-2018-24-F1-EN-ANNEX-1-PART-1.PDF

Malykhin, O. (2016). Formuvannia indyvidualnykh stratehii navchannia zasobamy kompiuternykh tekhnolohii yak pedahohichna problema. Visnyk Chernihivskoho natsionalnoho pedahohichnoho universytetu imeni T.H. Shevchenka, 133, 124-127.

Malykhin, O. (2010). Informatsiino-navchalne seredovyshche yak zasib efektyvnoi orhanizatsii samostiinoi navchalnoi diialnosti studentiv vyshchykh pedahohichnykh navchalnykh zakladiv. Naukovi zapysky Ternopilskoho natsionalnoho pedahohichnoho universytetu imeni Volodymyra Hnatiuka, 3, 33-38.

Malykhin, O., \& Aristova, N. (2019). Improving computer engineering and information technologies undergraduate students' training through combination of formal, non-formal and informal learning. Vide. Tehnologija. Resursi, 2, 208-213. DOI: http://dx.doi.org/ 10.17770/etr2019vol2.4113 
Malykhin et al., 2020. The Dichotomy of Information Technologies in Professional Training of Future it Specialists: the Subject and the Means of Instruction

Malykhin, O., \& Aristova, N. (2018). Investigation into participation activity rate of foreign languages teachers in specially focused network pedagogical communities. The New Pedagogical Review, 53(3), 227-238. DOI: 10.15804/tner.2018.53.3.19

Malykhin, O., Kovalchuk, V., Aristova, N., Popov, R., \& Hrytsenko, I. (2017). Stratehii intensyfikatsii vyshchoi humanitarnoi osvity $v$ Ukraini ta krainakh YeS: monohrafiia. Kyiv: NUBiP Ukrainy.

Vuorikari, R., Punie, Y., Carretero Gomez, S., \& Van den Brande, G. (2016). DigComp 2.0: The Digital Competence Framework for Citizens. Update Phase 1: The Conceptual Reference Model. Luxembourg Publication Office of the European Union. EUR 27948 EN. DOI: 10.2791/11517 